\title{
HUKUM DAN DEMOKRASI JALAN MENUJU KESEJAHTERAAN RAKYAT
}

\author{
Andi Nuhrawati \\ Universitas 19 November, Kolaka, Sulawesi Tenggara
}

\begin{abstract}
Abstrak
Penegakan hukum dan demokrasi memiliki relevansi yang erat dengan masalah-masalah hukum, misalnya korupsi, kolusi dan nepotisme. Penelitian ini menunjukkan ketidak adilan yang dirasakan kaum menengah kebawah, yaitu tajamnya hukum mengiris kebawah dan tumpulnya keatas. Olehnya dalam tulisan ini mempertanyakan hukum dan demokrasi membangun bangsa dan relevansinya terhadap kepemimpinan bangsa Indonesia,serta mempertanyakan peningkatan martabat manusia dan kesejahteraan melalui pembudayaan kritikan demi kemajuan. Hasil pemikiran dalam tulisan ini menunjukkan terpeliharanya stabilitas dan keamanan dalam sebuah negara tidak hanya ditentukan kekuatan personil polisi dan angkatan bersenjata, namun harus pula dibangun pula lembaga hukum yang berwibawa dan disegani masyarakat, melalui aparataparat hukum dan lembaga hukum harus mampu menjaga citranya dalam masyarakat secara ketat,sebab hanya beberapa orang saja yang melakukan perbuatan tidak terpuji maka stigma buruk akan cepat lekat dalam pikiran masyarakat. Masyarakat miskin yang dikaji dalam tulisan ini lebih terfokoskan dalam pengertian ekonomi, yaitu mereka yang tingkat pendapatan sangat rendah sehingga kesulitan untuk memenuhi kebutuhan hidupnya sehari-hari. Pertama harus dijawab dari gambaran masyarakat miskin diatas apakah mereka merupakan sebuah kelas politik atau bukan,kalau mereka tergolong dalam kelas politik itu artinya keberadaan mereka diperhitungkan, disadari dan diyakini kekuatannya oleh partai politik. Tetapi,kalau kelompok masyarakat miskin dinilai bukan sebuah kelas politik mereka hanya dimanfaatkan sebagai objek oleh kekuatan politik, tidak akan mendapatkan keistimewaan tertentu
\end{abstract}

Kata kunci: Hukum dan Demokrasi; Kesejahteraan Rakyat, Politik Hukum

\section{PENDAHULUAN}

Masalah penegakan hukum dan demokrasi tidak pernah habis-habisnya muncul di Indonesia . Akhir-akhir ini banyak terjadi,berbagai kasus berkaitan dengan masalah hukum,seperti korupsi,suap menyuap,krinalitas tingkat tinggi,kejahatan seksual, adanya fasilitas mewah di penjara, penggusuran, tuduhan pencemaran nama baik dan lain sebagainya. Dan sebuah kasus yang menyita perhatian juga muncul yaitu masalah ketidakadilan dalam hukum yang dirasakan rakyat kecil dalam kasus-kasus pencurian yang tidak seberapa nilainya,tapi mendapat vonis hukum yang dirasakan tidak pantas.

Sedangkan yang berhubungan dengan persoalan demokrasi kita melihat munculnya ketidakpuasan dalam hasil-hasil pemilihan pilpres, kepala daerah, bupati. Kemudian maraknya unjukrasa mengungkapkan ketidakpuasan terhadap kinerja pemerintah, misalnya,dalam kasus pemberian fasilitas mewah bagi para pejabat dan wakil rakyat yang dinilai tidak mencermingkan kepekaan sosial,dan dalam kasus Bank Century yang sampai saat ini masih kurang jelas.Dari persoalan penegakan hukum dan demokrasi ini tampak dengan jelas potensi untuk 
melahirkan ketidakstabilan dalam masyarakat. Itulah sebabnya, masalah pembangunan dibidan hukum dan menanamkan kesadaran hukum sangat penting perannya.

Salah satu tujuan dari berlakunya aturan hukum dalam masyarakat adalah untuk menciptakan ketertiban sosial. Semuanya ini bisa terwujut kalau masyarakat memiliki sikap disiplin dan memiliki kesadaran hukum yang tinggi. Biasanya,kalau kesadaran ini sudah kuat,masyarakat juga memiliki budaya malu (sham culture) yang tinggi. Masyarakat merasa malu melanggar hukum dan merasa malu berbuat yang tidak baik. Misalnya,di Singapura masyarakat memiliki disiplin yang tinggi karena penegakan hukum berjalan dengan baik sehingga kalau menyeberang tidak tertib dianggap sebagai prilaku yang rendah.Dan di Jepang,pejabat yang melakukan perbuatan melanggar hukum akan merasa malu sehingga melakukan harakiri atau bunuh diri karena merasa dirinya hina.

Di Indonesia,masalah kesadaran dan kepatuhan pada hukum masih amat rendah.Bukan hanya di lapisan masyarakat luas, di tingkat elit, pejabat,wakil rakyat, professional dan pengusaha masih memprihatinkan kesadaran hukumnya. Dimasayrakat luas, sikap ini tercermin dalm prilaku berlalulintas, bentrokan massa dan berbagai kerusuhan. Ditingkat masyarakat menengah keatas prilaku iniditujukkan dalam berbagai prilaku jalan pintas,sikap menerabas,cara instant mencapai tujuan meski dengan jalan melanggar hukum. Banyak pejabat dan pengusaha yang dimeja hijaukan setelah dibuktikanya KPK ( komisi pemberantas korupsi ) memperlihatkan bahwa kesadaran hukum para pejabat belum bisa dikatakan memuaskan.

Penegakan hukum dan sedaran hukum di Indonesia seperti benang kusud susah dari mana harus dimulai. Pendekatan kultural dan pendidikan meruupakan salah satu yang dianjurkan,pendekatan lain dianjurkan agar sikap disiplin dan patuh pada hukum diterapkan di lembaga atau diinstansi manapun kita berada. Masalah penegakan atau masalah menumbuhkan kesadaran hukum dalam masyarakt merupakan usaha yang tidak boleh berhenti. Upaya menumbuhkannya harus dilakukan di semua lini kehidupan, mulai dari rumah tangga,sekolah,lingkungan dan masyarakat. Yang paling penting para pejabat dan aparat pemerintah,para tokoh masyarakat memiliki pengaruh yang sangkat penting. Mereka inilah yang seharusnya menujukkan keteladanannya sebagai hamba hukum yang baik sehingga masyarakat mencontoh dan meningkatkan prilaku meraka,bukan malah menujukkan prilaku yang menyimpang sehingga masyarakat berfikir yang negatif kepada mereka, harus dilakukan sebuah gerakan kultural dalam masyarakat kita yang dilaksanakan semua lapisan masyarakat untuk menjadikan kepatuhan pada hukum sebagai bagian penting dari kehidupan sehari-hari.

Mengenai kehidupan demokrasi yang dicerminkan dalam bentuk kekecewaankekecewaan masyarakat dalam pemilu, pilpres, pilkada, pilbub memang masih terdapat berbagai kelemahan dalam teknis pelaksanaan. Semua itu harus selalu kita evaluasi dan diambil sebagai pengalaman untuk penyelenggaraan pesta demokrasi di masa yang akan datang hingga lebih sempurna dan memuaskan masyarakat. Sistem pemilu yang diterapkan secara langsung sekarang ini memang merupakan kemajuan dalam sistem politik kita,namun dengan adanya semua itu kita berharap semakin mendewasakan prilaku politik kita dan berhasil mewujutka kehidupan berbangsa dan bernegara yang berkualitas.

Berdasarkan pada uraian latar belakang masalah tersebut di atas, maka 
dapat dirumuskan permasalahan sebagai berikut :

1. Bagaimana hukum dan demokrasi membangun bangsa dan relevansi kepemimpinan Indonesia

2. Bagaimana meningkatkan Martabat manusia dan kesejahtraan negara dan membudayakan kritik untuk mencapai kemajuan

\section{PEMBAHASAN}

\section{Hukum dan Demokrasi dapat Membangun Bangsa}

Membangun lembaga hukum yang berwibawa sangatlah penting untuk mencapai tujuan kita sebagai bangsa yang bermartabat, sebagaimana yang tercatum dalam undang-undang dasar 1945. Kita sering menyebut dengan bangga sebagai bangsa yang berbudi luhur,menghargai tata kerama,sopan santun dan menilai tinggi martabat dan harkat manusia. Sebagai bangsa yang religius kepada kita juga ditanamkan pentingnya toleransi dan menghargai setiap perbedaan keyakinan dan menjaga persatuan dan kesatuan bangsa.

Tetapi,yang membuat kita geleng kepala akhir-akhir ini dalam masyarakat kita muncul prilaku kekerasan yang amat tidak sesuai dengan ungkapan budaya luhur yang acap kita agungkan tersebut.Bahkan,kalau lihat prilaku kekerasan yang terjadi dalam masyarakat amat bertentangan dengan nilai luhur yang kita banggakan. Dan masih banyak prilaku kekerasan yang dipilih oleh masyarakat sebagai cara instan untuk menyelesaikan masalah.Prilaku kriminalitas seperti, membunuh, melukai dan melenyapkan nyawa orang untuk mendapatkan sejumlah materi dengan mudah. Ditingkat idiologis dan agama orang melakukan tindak teroris dan kebrutalan untuk menujukan eksistensinya keyakinanannya. Sedangkan di tingkat politis cara-cara melenyapkan nyawa orang diambil sebagai jalan pintas untuk membungkam sikap kritis seseorang.

Membudayakan kekerasan untuk menyelesaikan masalah jelas merupakan kecenderungan yang amat berbahaya. Pertama, menujukkan masyarakat mengalami degradasi moral dan merosotnya kualitas etika-budaya masyarakat. Kedua,kekerasan dan prilaku kriminalitas yang menonjol dalam masyarakat menujukan bahwa negara tidak mampu memberikan rasa aman buat rakyatnya. Negara dengan kelemahan seperti ini jelas tidak memiliki kewibawaan,sebab mandat yang sudah diberikan untuk memegang dan mengelola kekuasan tidak mampu dioptimalkan untuk mengendalikan keamanan.

Dengan demikian, pertanyaan mendasar yang dikedepankan jika terjadi instabilitas atau maraknya kejahatan dalam masyarakat maka perlu adanya evaluasi terhadap kinerja yang bertugas di bidang hukum dan kamtibmas. Terpeliharanya stabilitas dan keamanan dalam sebuah negara tidak hanya ditentukan kekuatan personil polisi dan angkatan bersenjata, namun harus pula dibangun pula lembaga hukum yang berwibawa dan disegani masyarakat. Dengan demikian juga, kondisi ekonomi dan pendidikan masyarakat harus terus ditingkatkan sehingga melahirkan masyarakat yang berkualitas, bukan menonjolkan kekuatan dan cara-cara yang bersifat fisik.

Perlunya kita membangun masyarakat yang memiliki kesadaran hukum yang tinggi karena kualitas penegak hukum baik polisi,jaksa,hakim dan pengacara jumlahnya terbatas dibandingkan jumlah penduduk. Polisi dan masyarakat, komposisinya 1:500. Dengan perbandingan tersebut tidak mungki seorang polisi dapat melayani keamanan orang memuaskan. Untuk mengatasi 
masalah ini pendekatan yang terbaik dilakukan adalah membangun kesadaran hukum masyarakat. Artinya, kualitas masyrakat harus ditingkatkan sehingga prilaku yang bertentangan dengan hukum semakin diminimalisir. Kedua Masyarakat dan polisi bersinergi dan membangun kemitraan dalam mengatasi kejahatan sehingga bisa ditekan dan tidak tumbuh dengan cepat.

Ketiga, polisi dan masyarakat berkerjasama membangun suasana atau persepsi bahwa penjahat harus takut kepada masyarakat, bukan sebaliknya yang terja dimana masyarakat yang takut pada penjahat, tentu saja kita bermaksud bahwa massa menjadi hakim untuk menghukum pelaku kejahatan. Betapapun kita tidak setuju dengan hukum rimba, namun jika masyarakat sudah terdidik dengan kesadaran hukum yang tinggi, tentu kita yakin mereka akan melakukan tindakan sesuai dengan kepatuhan hukum dan perundang-undangan.

Yang perlu kita lakukan sekarang adalah bagaimana cara yang efektif membangun kesadaran hukum masyarakat. Dalam hal ini harus ada keteladanan dan contoh-contoh yang diperlihatkan atau dipelopori oleh para pejabat dan mereka yang berwenang dibidang hukum itu sendiri. Peraktek-praktek hukum harus diterapkan dengan adil, siapapun yang melakukan kesalahan harus diberikan sanksi yang sesuai pelanggaran yang diperbuatnya. Dengan hukum yang diterapkan secara adil maka hukum menjadi berwibawa di tengah masyrakat.

Aparat-aparat hukum dan lembaga hukum harus mampu menjaga citranya dalam masyarakat secara ketat,sebab hanya beberapa orang saja yang melakukan perbuatan tidak terpuji maka stigma buruk akan cepat lekat dalam pikiran masyarakat. Itulah sebabnya, masyarakat yang patuh pada hukum akan selalu melihat kepada aparat penegakkan hukum. Jika mereka mampu melakukan,menujukkan loyalitas dan komitmen yang tinggi pada hukum maka masyarakat akan mengikuti apa yang mereka anjurkan. Tetapi, jika sebaliknya bemberikan contoh yang tidak sesuai atau melanggar aturan-atauran yang telah

Demokrasi dalam pengertian budaya dan sikap hidup prilaku yang menujukkan komitmen dan pengharggan pada nilai-nilai kemanusian. Sebuah sikap yang menafikan arogansi dan kesombongan, sebaliknya menghargai martabat manusia sebagai mahluk yang dimulakan Allah pencipta semesta ini.Dengan demikian dalam demokrasi sebagai sistem budaya,manusia dinilai sama derajadnya. Tidak ada pebedaan yang menyebabkan manusia ditempatkan sebagai memiliki derajat rendah dan tinggi.

Dalam demokrasi,seseorang dinilai tinggi keberadaannya bila ia mampu menghormati manusia sebagai manusia,bukan karena manusia itu memiliki berbagai kelebihan baik material maupun status dan kedudukannya dalam masyarakat. Seorang demokrat adalah seorang yang berjuang dan membangun dirinya untuk menjadi pribadi yang human, bersahabat dengan orang lain,terbuka,ramah,santun kepada siapapun, tampa memiliki perasangka buruk dan kecurigaan kepada siapa saja.

Seorang demokrasi adalah yang selalu membuka diri untuk berdialaok, bersedia berdeda pendapat tanpa harus berkonflik dan tetap menjaga persahabatan dengan baik. Demokrasi sejati tidak mungkin bersikap otoriter dan membungkam pikiran dan pendapat orang lain, sebaliknya. Namun ruang kebebasan berbicara, berpendapat dan beraktivitas yang dibuka secara luas tentulah tetap dalam koridor rasa tanggung jawab. Bagaimanapun suatu kebebasan yang lepas kendali bisa menyebabkan terganggunya tertib sosial dan keamanan masyarakat. Dengan 
begitu,seorang demokrat berfikir jauh ke depan dan mampu melihat akibat dari sebuah gagasan yang dikembangkannya.

Ciri selanjutnya budaya kehidupan berdemokrasi adalah berlakukanya kekuatan hukum dalam segala kehidupan (law enforcement). Supermasi hukum menjadi alat kontrol pengatur prilaku seluruh masyarakat dan diterapkan secara adil tanpa memberikan perlakuan khusus pada siapapun. Dalam mengimplementasikan kekuatan hukum tidak ada prilaku tembang pilih dan pilih kasih. Hukum yang berkeadilan harus dilaksanakan apapun konsekuensi yang harus dihadapi.

Tetapi, tentu harus ada usaha dalam masyarakat yang merangsang dan berupaya membangun masyarakat agar sadar dan patuh pada hukum. Dalam masyarakat yang mempunyai keinginan kuat untuk menerapkan nilai-nilai demokrasi harus selalu ada figur yang intens berfikir dan bekerja untuk membangun masyarakat yang sadar hukum. Pesoalan yang berkaitan dengan hukum dan hak asasi manusia di negara kita tergolong berat. Jumlah orang miskin yang masih besar masih merupakan beben yang belum terpecahkan oleh pemerintah, baik untuk meningkatkan pendapatan, pendidikan dan kualitas hidup merika. Kesenjangan antara yang miskin dan kaya merupakan bibit subur terjadinya komflik dan ketegangan,serta penindasan hak asasi manusia.

Walaupun faktor pendidikan tingkat kesejahtraan bukan menjadi sebab utama terbentuknya kesadaran hukum, tetapi paling tidak masyarakat yang secara ekonomi lebih baik dan terdidik cukup kuat kemauannya untuk mematuhi hukum. Dalam rangka pembangunan kesadaran hukum masyarakat maka secara berbarengan harus pula ditingkatkan kesejahtraan dan pendidikan masyarakat.
Saat ini kita melihat betapa masyarakat lemah harus berjuang untuk bertahan hidup. Mereka cukup memiliki kreativitas bergelut di sektor informal. Di tengah keterbatasan pemerintah dalam menyediakan lapangan kerja mereka mampu memenuhi kebutuhan hidup, kurang mendapat akomodasi dari pemerintah, baik modal mapun perlindungan sehingga sering berbenturan dengan pihak keamanan. Padahal, mereka melakukan suatu untuk survive dalam hidup sebagai bagian dari hak asasi yang harus dilindungi dan dijamin oleh konstitusi.

Dalam hal ini, pemerintah harus lebih serius membangun birokrasi yang efisien yang jauh dari kebocoran korupsi. Jika kita liat kasus-kasus korupsi produktif yang akhir-akhir ini terungkap dan dibawa ke jalur hukum, besar kekayaan negara yang mengalir keberbagai pribadi dan lembaga. Bagawan ekonomi sumitro pernah mengatakan $30 \%$ dari APBN di korupsi. Yang seharusnya dana yang raib ini menjadi dana yang di peruntukkan membangun masyarakat yang berada di bawah garis kemiskinan, baik untuk memberdayakan ekonomi mereka,pendidikan,kesahatan dan lain-lain yang bermanfaat untuk kesejahtraan masyarakat.

Masyarakat yang hidup dalam nilainilai demokrasi adalah yang selalu terpanggil memperjuangkan kehidupan yang lebih baik. Mereka menempatkan kepentingan orang banyak di atas yang lainnya; mereka selalu ingin memperbaiki struktur masyarakat yang timpang,baik dari segi ekonomi, pendidikan,status sosialnya. Demokrasei dengan asasnya kedaulatan berada ditangan rakyat mengadung makna kesejahtraan rakyatlah yang utama ingin diwujutkan, bukan kepentingan penguasa dan aparat -aparatnya. Dalam demokrasi, kepala pemerintahan para pejabatnya adalah 
pelayan yang bekerja untuk kesejahtraan rakayat.

Dengan demikian seorang demokrat adalah yang memiliki jiwa kenegarawanan, punya rasa sensisitivitas sosial yang tinggi pada nasib dan persoalan hidup yang dihadapi orang banyak. Mereka ikut bertanggungjawab untuk mencarikan penyelesaian penderitaan yang dialami masyarakat. Mengutamakan kepentingan orang banyak dari pada kepentingan peribadi. Pemerintah dan pejabat yang demikianlah yang kita harapkan lahir dengan pembangunan demokrasi yang kita inginkan tumbuh.

\section{Meningkatkan Martabat Manusia dan Kesejahtraan Negara, Membudayakan Kritik untuk Mencapai Kemajuan}

Hakikat pembangunan adalah untuk mensejahtrakan manusia. Jika pembangunan menyebabakan terjadinya penderiataan bagi manusia itu adalah sebuah tragedi dan kegagalan bagi penguasa yang menjalangkan pemerintahan. Pembangunan yang berhasil adalah yang meningkatkan martabat manusia bukan sebaliknya merendahkan harkat kemanusian.

Sebagai gambaran, pembangunan yang menyebabkan terjadinya penggus uran pemukiman penduduk dengan ganti rugi yang tidak memadai sehingga masyarakat merosot kualitas hidupnya dibangingkan sebelum digusur adalah pembangunan yang gagal. Sebab, keberhasilan pembangunan tidak bisa diukur hanya secara matematika dan indikator kemajuan fisik semata. Secara etika, pembangunan harus mensejahtrakan secara keseluruhan, bukan hanya dinikmati sekelompok orang. Pembangunan juga jangan melahirkan perbudakan sebagai akibat yang hanya melahirkan kelompok minoritas yang menikmati keunggulakeunggulan tertentu dan melahirkan arogasi terhadap masyarakat yang lemah.
Pembangunan yang dilihat dari perspektif martabat manusia melihat bahwa kemajuan manusia tidak hanya dilihat dari segi peningkatan kualitas diri individu semata. Ukuran kemajuan tidak cukup hanya dilihat dari jumlah materi yang berhasil dikumpulkan, skill yang dimiliki, kemampuan dalam mengoprasikan iptek, gelar keserjanaan, tetapi sejauh mana martabat dan moral masyarakat telah mengalami kemajuan. Sejauhmana setiap orang menghargai dan memuliakan martabat manusia, kalau apresiasinya sudah cukup tinggi dalam menhargai martabat manusia, maka itulah ciri manusia sejati yang telah mengalami kemajuan.

Martabat mausia harus dihargai dan menjadi tolak ukur dalam melihat kemajuan sebuah masyarakat dan individu. Sebab manusia adalah mahluk yang berakal budi dan memiliki beberapa keistimewaan dan keunggulan. Dalam pandangan semua agama bahwa manusia adalah yang tertinggi derajatnya diciptakan oleh Allah.

Ada beberapa keistimewaan manusia yang menyebabkan harkat dan martabatnya harus dihargai,tanpa melihat asal usulnya.Yang,pertama manusia dalah mahluk yang paling mengerti mengenai kebenaran. Kedua manusia memili kemauan bebas dan dapat menentukan sikap dan tindakannya sendiri. Dalam agama islam menjelaskan bahwa manusia adalah mahluk yang paling mulia diciptakan oleh Allah dibandingkan mahluk lainnya. Dalam surat al-Isra ayat 70 dikatakan," Sesungguhnya kami muliakan Bani Adam(manusia), kami tempatkan mereka di darat dan dilaut,Kami beri rizki dari yang baik-baik, dan Kami lebihkan mereka dengan kelebihan yang banyak dibandingkan mahluk lainnya yang kami janjikan".

Dengan kelebihan, keistimewaan dan akal manusia menyadi adanya Tuhan yang harus ditaatinya. Karena akal itu pula manusia melahirkan kebudayaan, mengolah 
benda-benda alam jadi benda-benda budaya menurut kebutuhan hidupnya. Akal juga yang membuat manusia menjadi mahluk bermoral,menciptakan norma-norma sosial untuk kerukunan hidup bersama. Dengan semua yang dimiliki oleh manusia yang diberikan oleh Tuhan, nyatalah bahwa manusia itu adalah mahluk yang terhormat,dan harus di jaga martabat dan kedudukannya,dan tidak boleh direndahkan. Semua aktivitas manusia baik dalam lingkup budaya, politik, ekonomi, dan lainnya haruslah merujuk pada penghargaan martabat manusia. Jika komitmen dan konsistensi dalam pembangunan ini sudah cukup tinggi dalam menghargai martabat manusia dalam aktifitas sosial, budaya, ekonomi dan politik itu berarti hakekat dari tujuan pembangunan sejati telah tercapai.

Saat ini pembangunan berjalan dengan pesat,namun terjadi berbagai ketimpangan dan merosotnya harkat dan martabat manusia disebabkan pembangunan tidak lagi megidahkan dan menghagai martabab manusia. Pembangunan hanya bertumpu mengejar pertumbuhan materi, akibatnya segala sesuatu yang dapat memberikan keuntugan materi dianggap sebagai komoditas, termasuk dalam hal ini manusia juga dianggap sebagai barang yang kalau mendatangkan keutungan.kita melihat adanya perdangan anak, pelacuran, ekspor TKW tanpa memperhatikan perlindungan, mafia, backing, banditisme dan perilaku kriminalitas dan kekerasan demi mengejar kekayaan ekonomi dan keserahkahan. Dalam konteks ini manusia sebagai mahluk terhotmat ,mahluk yang ditinggikan Allah derajatnya jatuh harkatnya karena pembangunan hanya melihat aspek pertumbuhan materi semata

Pemikiran jangka pendek yang hanya melihat mementingkan kebijakan ekonomi sudah saatnya ditinjau kembali, mengigat dampak dan impikasi soaial yang diperhatikan. Kita harus lebih serius memperhatikan aspek hukum dalam pembangunan ekonomi sehingga manusia benar-benat diperlakukan sebagai subyek yang berhak mendapatkan kesejahtraan, dihargai eksistensinya, dihormati sebagai mahluk Allah yang mulia, bukan diekspoitasi dan dijadikan obyek oleh pembangunan itu sendiri.

Sebuah negara yang maju bukan hanya dilihat aspek fisik dan pertumbuhan ekonomi saja,namun juga bagaimana perlakuan negara terhadap orang-orang lemah. Negara dengan kemampuan menjamin kehidupan setiap warganegaranya yang mengalami kekurangan sehingga mereka merasa dihargai, itulah negara yang diakui kemajuannya secara lahir dan batin.

Negara kesejahtraan adalah konsep negara yang diperhatikan tertuju secara total untuk melindungi dan membantu warganegaranya sehingga mereka yang lemah, tua, cacat fisik, miskin, tidak bekerja dan lainnya dapat dibantu sehingga tidak menderita dalam kehidupan. Secara riil welfare state hanya bisa terwujud dinegara yang ekonominya sudah maju. Negara yang miskin tentu saja sukar merealisasikan konsep negara kesejahteraan, meski secara konsepsi-perundangan-perundangan

terhadap gagasan untuk itu,tetapi realisasinya sangat sulit karena perekonomiannya tidak mendukung.

Namun, implementasi negara kesejahtraan harus dilakun dengan hati-hati karena meskipun tujuannya adalah baik,tetapi bisa berdampak negatif dalam jangka panjang antara lain melumpuhkan semangat kompetitif yang amat dibutuhkan sebuah bangsa yang ingin kuat. Jamina sosial bila dilakukan harus kt perhatikan dengan baik sebab hal ini dapat menjadikan masyarakat malas yan membuat kehilangan spirit daya juang menghadapi tantangan hidup. Bila ini terjadi maka jaminan sosial yang tujuannya hendak membantu masyarakat akan menjadi bumerang 
menjadikan masyarakat lemah dan kehilangan inisiatif. Dalam jangka panjang bangsa tersebut akan mengalami stagnasi dalam bidang ekonomi maupun bidang lainnya.

Jaminan sosial ini bila tidak dikelolah dengan menejemen yang baik dan efektif yang terjadi adalah justru pemborosan dan penyalahgunaan keuangan negara. Untuk itu diperlukan ketelitian dan kecermatan dalam pengelolaannya sehingga maksud dan tujuan dari jaminan soaial itu hasilnya sesuai dengan harapan yang kita harapkan. Dalam kaitan ini pemerintah dan masyarakat harus tetap mengkampanyekan atau menanamkan nilai-nilai dalam masyarakat bahwa bekerja merupakan sebuah kewajiban bagi setiap orang untuk bekerja secara baik dan bermutu merupakan hal yang harus ditanamkan kepada masyarakat. Kita harus menghilangkan pemikiran bahwa dalam negara kesejahtraan jangan sampai timbul kesan bahwa masyarakat dalam segala hal menggantungkan hidupnya kepada negara. Sebab,mentalitas seperti ini yang tumbuh itu artinya masyarakat kehilangan dinamika, semangat kreativitas, inisiatif dan prakarsa yang merupakan kunci kemajuan sebuah bangsa (Sayidiman Suryohadiprodjo,PT Gramedia, 1987).

Segi lain penting juga diperhatikan agar masyarakat memiliki tradisi menghemat atau menabung,menjauhi prilaku boros dan konsumtif, yaitu berbelanja keperluan-keperluan yang tidak penting. Bagi Indonesia mewujutkan Negara Kesejahteraan tampaknya masih panjang jalan harus ditempuh. Kondisi perekonomian yang sulit menyebabkan anggaran pemerintah belum memadai untuk menjamin kehidupan masyarakat, jangankan untuk menjamin kehidupan orang-orang yang cacat fisik,untuk yang normal pun belum seluruhnya dapat diakomodasi aspirasi mereka, misalnya, dalam penyediaan lapangan kerja, pendidikan dan lain-lain. Dalam kehidupan sehari-hari begitu mudah kita liat masyarakat yang belum tertampung atau tersalurkan kebutuhan mereka sehingga terpaksa`menjadi penganggur, memintaminta, pekerja seksual, pengamen, pedagang kaki lima yang diburu-buru, kemudian anakanak yang tidak mengenal pendidikan dan masik banyak lagi kasus yang kita dapati di tegah-tegah masyarakat kita.

Dalam kondisi keuangan pemerintah yang sulit sekarang ini, mewujutkan negara kesejahtraan masih merupakan utopia. Yang hanya bisa diharapkan sekarang ini adalah menumbuhkan empati dan rasa solidaritas sosial dalam masyarakat, dimana perlu ditumbuhkan prilaku dan semangat berkobar dikalangan orang-orang berpunya untuk membantu masyarakat yang belum beruntung, yaitu dengan bantuan yang produktif dn berdayaguna,misalnya menjadi orang tua asuh membiayai pendidikan, memberikan modal usaha,dan lain-lainnya yang intinya membantu orang miskin menjadi mandiri hingga dapat menolong diri sendiri.

Walaupun dalam undang-undang kita dikatakan "fakir miskin dan anak-anak yang terlantar dipelihara oleh negara" namun kenyataannya tidak demikian, masih banyak yang tidak mendapat perhatian akibatnya terpaksa hidup mengharap belas kasihan orang lain. Arinya undang-undang ini tidak sesuai dengan kenyataan dikehidupan masyarakat, implemtasinya hingga saat ini masih jauh dari harapan.

Dalam hal ini saya sependapat dengan sebuah konsep yang cukup baik terutama yang bersumber dari agama khususnya Islam yang memiliki ajaran mengenai zakat, sebuah kewajiban bagi umat islam yang mampu untuk mengeluarkat zakat yang harus diberikan kepada fakir miskin. Hanya saja pelaksanaannya selama ini masih berjalan secara tradisional,belum dikelolah dengan menejemen yang baik sehingga 
hasilnya untuk memerang kemiskinan dan membantu orang-orang yang membutuhkan outputnya belum optimal. Saya yakin bahwa zakat dikelolah secara baik bisa memberikan kontribusi yang positif dan mendukung tercapainya konsep negara kesejahtraan.

Disamping itu upaya pemerintah dalam memberantas korupsi kita harapkan tetap konsisten dan tuntas, sehingga para koruptor yang sebenarnya tidak menghabiskan keuangan negara benar-benar dapat dilenyapkan sehingga keuangan negara dapat dimanfatkan untuk menghapus kemiskinan di negara tercinta kita ini.

Sebab secara mudah kita melihat dalam masyarakat yang hidup dalam garis kemiskin,tingkat pengangguran semakin meningkat,dan masih banyaknya propesi yang bertentangan dengan nilai-nilai melanggar hukum seperti pencuri,pengedar sabu-sabu,copet,dan lain-lain yang tidak mungkin disebut satu persatu. Masyarakat yang hidup dalam taraf ekonomi lemah dan miskin dengan mudah mereka-mereka dijadikan sebagai subjek politik, pertanyaanya apakah dunia politik bermakna buat mereka. Apakah berpartisipasi dalam politik bisa merubah kehidupannya. Pertanyaan sebaliknya apakah organisasi politik melihat masyarakat miskin memilih kekuatan tawar yang dapat diperhitungkan?

Memperhatikan tiga jenis kelompok masyarakat miskin:

1. kelompok msyarakat dhuafa, yaitu kelompok masyarakat yang tidak meperoleh hak-hak asasinya,baik hak sipil,politik,kebudayaan maupun hak keberagamaan. Mereka kelompok yang tertindas oleh rejim,dan hak berbudaya untuk lolos dari tidak penidasan.

2. kelompok masyarakat fugar,adalah kelompok masyarakat yang menderita karena tidak memperoleh kesempatan unruk memasuki lapangan kerja, baik kerja mandiri berwiraswasta,bekerja menjadi buruh atau karyawan.

3. kelompok masyarakat miskin,yaitu kelompok masyarakat yang tidak memberoleh distribusi pendapatan secara adil,sehinga pelapisa masyarakat terdapat yang sangat kaya sampai yang sangat miskin atau di bawah garis kemiskinan.

Masyarakat miskin yang dikaji dalam tulisan ini lebih terfokoskan dalam pengertian ekonomi, yaitu mereka yang tingkat pendapatan sangat rendah sehingga kesulitan untuk memenuhi kebutuhan hidupnya sehari-hari. Pertama harus dijawab dari gambaran masyarakat miskin diatas apakah mereka merupakan sebuah kelas politik atau bukan,kalau mereka tergolong dalam kelas politik itu artinya keberadaan mereka diperhitungkan, disadari dan diyakini kekuatannya oleh partai politik. Tetapi,kalau kelompok masyarakat miskin dinilai bukan sebuah kelas politik mereka hanya dimanfaatkan sebagai objek oleh kekuatan politik, tidak akan mendapatkan keistimewaan tertentu.

Kelompok masyarakat bisa menjelma menjadi kelas politik kalau mereka menggalang kebersamaan dan cita-cita atau keinginan untuk diwujutkan secara bersama.Fakror kohesi dan dorongan untuk berhipun secara bersatu secara organisatoris mewujukan diri sebagai sebuah kelompok besar menjadikan masyarakat miskin diakui dan disegani eksistensi dirinya oleh partai politik. Dalam hal inilah orang miskin diakui sebagai kelas politik yang pantas diperhitungkan.

Namun kenyataannya masyarakat miskin memiliki kendala untuk menjadi bagian kelompok politik yang diperhitungkan. Sebab faktor kesulitan ekonomi, keterbatasan wawasan pemikiran, dominasi kultur tradisional, sikap mental apatis merupakan penghalang bagi mereka untuk memperjuangkan perubahan nasib 
melalui jalur politik. Dalam politik, faktor yang sangat diperhitungkan adalah kekuatan yang didasarkan pada jumlah massa, kekuatan integrasi atau persatuan, semangat solidaritas untuk mencapai tujuan dan rasa senasib seperjuangan.

Dengan kenyataan inilah kita liat masyarakat miskin dalam politik hanya diperlakukan sebagai objek partai politik maupun kandidat yang sedang bersaing memperebutkan kursi jabatan hanya melihat suara masyarakat miskin yang ingin didapatkan. Dengan memberikan imingiming sembako dan janji-janji yang menyenangkan masyarakat, agar mereka terpilih. Namun kenyataan setelah mereka terpilih menjadi bupati,gubernur anggota dewan, janji-janji yang pernah dia ucapkan tidak lagi di ditepati.

Bagaimanapun juga pendidikan politik yang sehat harus diberikan kepada seluruh masyarakat. Tujuan utamanya adalah selain meningkatkane kecerdasan juga agar setiap kebijakan pemerintah dapat mengangkat harkat dan kesejahtran seluru lapis masyarakat,termasuk perbaikan kehidupan masyarakat miskin aktifitas politik yang bersifat membodohi harus dihindari dalam aktifitas politik. Sebaliknya,kegiatan politik wajib menyadarkan masyarakat akan hak dan kewajibannya,serta mendapat perlindungan dan keadilan dari pemerintah. Dengan demikian pendidikan politik dalam konteks masyarakat miskin adalah memberantas sikap apatisme,mendorong munculnya semangat berorganisasi

,penggalangan kebersamaan dan solidaritas untuk mencapai tujuan bersama, memunculkan pemikiran kritis, tapi semua ini ditujukan bukan untuk melahirkan prilaku radikalisme dan kerusuhan,tetapi sebagai warga negara yang sadar hakhaknya untuk diperhatikan dan dilindungi oleh kebijakan pemerint

Oleh sebab itu setip individu yang terbuka untuk dikeritik dan disingkapkan kelemahannya bakal menjadi individu yang memiliki mental yang kuat, sedangkan dikenakan kepada bangsa akan menjadikan bangsa tersebut besar dan maju. Karena,kritik yang ditanggapi secara positif memberikan kesempatan kepada seseorang atau bangsa mengetahui kelemahannya sehingga ia segera memperbaiki kekurangannya, baik itu datang dari musuh tetap dapat diambil sebagai pelajaran, karena dilakukan secara terbuka ingin mengungkapkan kelemahan kita. Dengan demikian banyak pelajaran yang dapat kita petik dari keritik seorang musuh. Berbeda jika keritik datangnya dari seorang sahabat atau orang yang dekat dengan kita, yang mengemukan secara sungkan,serba banyak pertimbangan. Akibatnya memerlukan pencernaan yang cermat untuk memahami.

Secara umum masyarakat kita belum bisa memberikan apresiasi terhadap kritik. Kritik masih dianggap sebuah serangan yang tujuannya menjatuhkan, bukan sebuah upaya koreksi untuk membangun diri dan menujukkan kelemahan untuk diperbaiki. Tiap-tiap daerah mempunyai budaya sendiri dalam menanggapi kritik. Dalam penyampaian harus ada tata kerama atau sopan santun, sehingga seorang pemimpin apabila dikritik tidak merasa dirinya dilecehkan atau di anggap dirinya dicemarkan. Sebagai contoh yang patut dihormati pada sikap Raja Thailan Bhumibol Adulyadey (90 tahun) ia bertahta selama 62 tahun, yang membukakan dirinya untuk dikritik. Ketika menasehati perdana mentirinya Thaksin Shinawatara (2005) Bhumibol mengatakan bahwa raja pun bisa berbuat salah, adalah lebih baik mengetahui kesalahan itu. "Peribahasa raja tidak mungkin salah merupakan pernyataan yang sangat menghina bagi raja. Mengapa raja tidak bisa berbuat salah, itu berarti raja bukan manusia. Raja bisa saja berbuat salah" ujar Bhumipol ketika menasehati 
sang Perdana mentri untuk terbuka terhadap kritik (Kompas, 6 Desember 2016 hal.8).

Berbagai dalil dikemukakan untuk menolak kritik. Ada yang mengatakan kritik harus disertai jalan keluar atau solusinya. Kritik tanpa solusi tidak lebih sikap permusuhan dan kebencian. Padahal,kalau kita mau diambil nilai positifnya kritik tanpa solusi pun merupakan suatu keuntungan bagi yang dikritik. Agar mendapatkan pengawasan secara gratis sehingga mengetahui kelemahan. Kedua ada yang mempermasalahkan kritik dari cara penyampaian. Sebuah kritik mungkin diakui kebenarannya,tetapi karena cara penyampain yang dinilai kasar maka kritik tersebut ditolak, meski diam-diam yang bersangkutan dapat menerima isi kritik tersebut.

Dalam hal ini kita harus memperhatikan psikologi masyarakat Indonesia. Dalam berinteraksi masyarakat kita sangat dipengaruhi etika pergaulan yang harus menjaga sopan santun. Sebuah kritik yang dilakukan secara blak-blakan, arogan, apalagi dengan bahasa yang menhujat dan menyalahkan, itu tidak efektif. Namun, lemahnya kritik yang dilakukan secara bijaksana,dengan bahasa santun, tepo seliro belum tentu efektif, sebab kurang diperhatikan, tidak berwibawa dan perlu kecermatan dalam memahaminya.

Ada juga orang yang dapat menerima kritik asal dilakukan ditempat yang tertutup,ia di tempat umum akan menjatuhkan wibawa dan reputasinya. Di lingkungan kritik bahkan sangat dibutuhkan. Dalam berbagai manajemen perusahan,dalam rangka evaluasi untuk melihat program perusahaan. Kritik tesebut dimaksud untuk melihat kelemahan,kekuatan,peluang dan tantangan. Dalam hal ini dapat memajukan perusahaan,karena dianggap baik dan menyenangkan karena dasar kebijakan dalam mentukan policy perusahaan.
Melihat dampak positif dari budaya kritik ini untuk memajukan masyarakat dan bangsa kita perlu menumbuhkan kebiasaan kritik ini sejak dini, baik kita awali dari lingkungan keluarga, pendidikan dan masyarakat.

Menghidupkan kritik merupakan bagian dari membangun demokrasi, sebuah sikap terbuka melihat beragam pendapat. Dalam era reformasi sekarng ini kita melihat sikap keterbukan makin kentara, hal ini pada masa orde baru mustahil untuk dilakukan, saat ini justeru dinilai biasa saja. Dalam aksi unjukrasa kita melihat beragam masalah dikecam habis-habisan. Dalam media elektronik juga kita melihat perdebatanperdebatan tajam yang menyoroti berbagai kebijakan dan juga dalam kampanye pemilu Legislatif dan pilpres kandidat tampil saling berdebat mengemukan keampuhan konsepnya masing-masing. Semuanya dilakukan secara terbuka disaksikan jutaan khalayak.

Meski ini berlangsung di kalangan akadenisi,intelektul,pejabat dan pengusaha,tentunya diharapkan bakal menular pada masyarakat. Dari kesebuah itu diharapkan bakal menular pada masyarakat. Semuanya ini merupakan proses pendidikan untuk mencerdaskan masyarakt dan membiasakan diri terbuka dengan kritik. Namun yang penting juga dikemukan disini adalah baik yang dikritik maupun yang menyampaikan kritk harus didasarkan kesungguhan untuk melakukan perbaikan. Bagi yang mengkritik,bukan punya pamrih dengan maksud tertentu,dan didasari rasa benci terhadap orang yang dikritik. Kritik harus punya motivasi ingin merubah keadaan ke arah yang lebih baik.

Dengan makin banyaknya media sekarang ini baik cetak maupun elektronik, dan kian bebasnya pers menyebarkan imformasi,serta terbukanya kesempatan semua orang untuk berbica, berbagai hal 
yang menyangkut kebijakan pemerintah disebarluaskan ke masyarakat.

\section{DAFTAR PUSTAKA}

Muchlis Patahna. Hukum dan demokrasi membangun karakter bangsa Cetakan September 2010. Penerbit : CV. Azkia Jaya

Robert A. Dahl, Demokrasi dan Para Pengkritiknya,Jilid II, Yayasan Obor Indonesia, Jakarta, 1992

Qamar, Nurul. "Supremasi Hukum dan Penegakan Hukum." 2011, AlIshlah, Jurnal Ilmiah Hukum, Fakultas Hukum Universitas Muslim Indonesia 13 (2).

Hidjaz, M. Kamal. "Efektifitas Penyelenggaraan Kewenangan Dalam Sistem Pemerintahan Daerah Di Privinsi Sulawesi Selatan." Disertasi Pada Program Pasca Sarjana Universitas Hasanuddin, Makassar (2007).

Hidjaz, Kamal. "Role of Local Institutions in Improving Human Resources at Government System in Indonesia." JL Pol'y \& Globalization 14 (2013): 37.

Muhammad Syarif Nuh, Muhammad Kamal. Politik Hukum: Dari Ius Constitutum ke Ius Constituendum. 2010, Makassar: PT. Umitoha Ukhuwah Grafika

Muhammad Kamal. Tanggungjawab Wakil Kepala Daerah dalam Perspektif Hukum Positif dan Hukum Islam. 2010, Jurnal Al-Ishlah: Jurnal Ilmiah Hukum. Fakultas Hukum Universitas Muslim Indonesia 12 (4) $33-45$ 